\title{
PRELIMINARY STUDY OF COAL MINING RECLAMATION USING FOREST PLANTS IN BARITO EAST DISTRICT, CENTRAL KALIMANTAN PROVINCE
}

\author{
Ermal Subhan \\ Environmental Science Study Program, \\ Post Graduate Study Program of Palangka Raya University, \\ Palangka Raya, Indonesia
}

\begin{abstract}
The problem of post-mining coal management through the reclamation of former mining land has become a national issue in Indonesia. One important thing is how to do land reclamation and restore the preservation of the natural environment. Reclamation characteristics are open space, high light intensity, high temperature and extreme fluctuation, low $\mathrm{pH}$ and degradation of the number of species both flora, fauna and soil microorganisms. Such characteristics cause not all types of plants can live on the land. Theoretically, the results of the suitability of forest plant cultivation land are specifically eucalyptus plants (Melaleuca leucadendra) and Sengon (Paraserianthes falcataria). This is necessary and important to be studied regarding the limiting factors and management efforts in the former coal mining land. This can provide information and thought contributions to maximize the reclamation activities of former coal mining using plants, which have a high enough sale value, are environmentally sound and sustainable while taking into account local wisdom.
\end{abstract}

Keywords: Reclamation, mining land, limiting factors, suitability, local wisdom

Cite this Article: Ermal Subhan, Preliminary Study of Coal Mining Reclamation Using Forest Plants in Barito East District, Central Kalimantan Province, International Journal of Advanced Research in Engineering and Technology (IJARET), 11 (1), 2020, pp 7-13.

http://iaeme.com/Home/issue/IJARET?Volume=11\&Issue=1

\section{INTRODUCTION}

According to Law Number 23 of 2014 (Law 23) concerning Regional Government, the authority to manage the mineral resource energy sector which was originally the authority of the Regency and City Governments is then transferred to the authority of the Provincial Government and the Central Government in accordance with applicable laws and regulations. Based on Law No. 4 of 2009 (Law 4) concerning mineral and coal mining, the definition of mining is part or all of the stages in the framework of research, management and exploitation of minerals and coal which includes general investigation, exploration, feasibility studies, 
construction, mining, processing and refining, transportation and sales, and post-mining activities.

In managing mineral and coal resources, entrepreneurs engaged in coal mining must have a mining business permit. Mining activities carried out by Mining Business Permit holders include: land clearing work, stripping overburden, unloading coal seams and transporting coal to both stock pile fields and ports for coal sales to buyers.

Problems with post-mining coal management through the reclamation of former mining land have become a national issue. One of the important things in the coal mining industry activities with the open pit method in Indonesia is how to carry out land reclamation and restore the preservation of the natural environment to be maintained (Lubis, 1997). Former mining mining land needs to be immediately reclaimed and replanted to restore the ecosystem and microclimate, soil fertility and water storage functions. Reclamation characteristics are open space, high light intensity, high temperature and extreme fluctuation, low $\mathrm{pH}$ and degradation of the number of species both flora, fauna and soil microorganisms. In addition, the soil became rich-organically toxic with low BOD/COD ratio (Al-Rosyid and Mangkoedihardjo, 2019). Such characteristics cause not all types of plants can live on the land (Rahmawaty, 2002).

The implementation of reclamation has not been done well. It still looks like the former excavation, most of which have been filled with water and arrangement. Replanting activities have not been carried out properly because some of the former mining land has not yet been planted and in areas where reclamation has been carried out partly planted has not been planted with crop cover and the growth of the Sengon tree (Paraserianthes falcataria) is uneven. This can be said of the lack of plant maintenance and care. In order to improve and refine the reclamation and revegetation activities, one way to overcome this problem is to conduct a reclamation study of former coal mining land using eucalyptus forest plants (Melaleuca leucadendra) and Sengon (Paraserianthes falcataria).

Both types of plants are considered by taking into account ecological, economic and social aspects so that they can provide benefits to the local community economy and local government in a sustainable manner. Ecologically the development of eucalyptus and sengon plants in degraded land, among others, is to support land conservation efforts and the use of marginal land into productive land. Economically the development of both plants can be used as a household scale business up to a large scale and socially does not cause social conflict.

The main objective of this preliminary study is to assess the feasibility of eucalyptus plants and Sengon with wood products which are very useful and have a high enough sale value, so that the reclamation of land for former coal mining is environmentally sound and sustainable while taking into account local wisdom.

\section{LOSS OF VEGETATION}

Qomariah research results (2003) concluded that, land appearance in locations where there is a former coal mining land was not followed by land rehabilitation treatment until the tenth year, the condition of the former mining land showed that plant species would be difficult to live and there were almost no signs of a sign of vegetation can grow. The process of rehabilitating vegetation is essential, because in addition to its function of securing the soil surface from erosion it also functions as a source of nutrients.

According to (Barrow, 1991) in the cycle of natural ecosystems one component is vegetation including biotic components which have functions such as prevention and control of erosion such as protecting the surface of the ground from the destructive power of falling raindrops, and can control to hold surface water scour ( run off). The function of vegetation 
can also improve the physical properties of the soil through biological activities carried out by bacteria, fungi, fungi, insects and earthworms that can improve the porosity and stability of soil aggregates (Adisoemarto, 1994).

Ecologically revegetation is part of the mine land reclamation program. In the implementation of revegetation of mining areas often experience difficulties due to the physical and chemical nature of the soil. The absence of topsoil is a general description of mining areas. Even if there is a nitrogen content that is very low so it does not meet the needs of plant growth. This situation is due to the absence of soil organic matter available by weathering dead plant material. In addition, the lack of soil microflora limits the decay of plant material. Conditions are also exacerbated by rocky surface layers, which complicates the development of vegetation due to low infiltration rates and water retention (Singh 2004).

\section{RECLAMATION}

Understanding reclamation according to Law Number 4 of 2009 (UU4) concerning Mineral and Coal Mining, it is stated that reclamation is an activity carried out throughout the stages of the mining business to organize, restore, and improve the quality of the environment and ecosystem so that it can function again in accordance with its designation.

Reclamation aims to improve or organize the use of disturbed land as a result of mining business activities, so that it can function and be efficient according to its purpose. Reclamation of former mining land in addition to an effort to improve post-mining environmental conditions, so as to produce a good ecosystem environment and also strived to be better than the initial baseline, carried out by considering the potential of minerals that are still left behind.

According to Sitorus (2003) a strategic step to repair damage caused by an open mining system is to return the remaining mining results into the holes in the mine opening (inpit filling). Re-vegetation by paying attention to the waste (tailings) that contain toxic materials. On post-coal mining land, land reclamation is an effort / effort to create so that the surface of the land can be stable, can sustain itself in a sustainable manner (self-sustaining). This former mining land can be used to produce again, starting from the relationship between land and vegetation, as a starting point for building new ecosystems. Reclamation of post-coal mining land associated with revegetation is basically to overcome the continued damage to land and create a process of nutrient formation through weathering falling leaf litter. This activity is expected to be sustainable and can form new ecosystems.

Reclamation activities are the end of mining activities which are expected to return the land to its original state, even if possible it can be better than the condition before mining. Reclamation activities include restoration of former mining land to improve ecological disturbed land and prepare former mining land whose ecology has been improved for further use. The final goal of the reclamation is to improve the former mining land so that conditions are safe, stable and not easily eroded so that it can be reused.

Technically, the mining land reclamation business consists of recontouring / regarding / resloping former mining holes. Besides making drainage channels to obtain the shape of the region with a stable slope. Top soil spreading activities to meet the requirements as plant growth media, so as to improve the soil as a planting medium. Revegetation is carried out using fast-growing plants, local native plants and introduced forestry plants. It is also necessary to plan the development of food crops, estate crops and / or industrial forest plants, if land use planning is possible (Djati, 2011). 
Preliminary Study of Coal Mining Reclamation Using Forest Plants in Barito East District, Central Kalimantan Province

\section{SELECTION OF PLANTS AS FORMER MINING LAND VEGETATION}

Based on Minister of Energy and Mineral Resources Regulation No. 18/2008 (PM18) concerning Mine Reclamation and Closure. The definition of reclamation as an activity aimed at repairing or staking land that is disturbed as a result of mining business activities, so that it can function and be efficient according to its purpose. By definition, the main purpose of reclamation is to make damaged areas better and more useful for humans. Reclamation aims at revegetation, which is replanting on former mining land so that it is beneficial to the ecology, economy and social, especially for the community around the mine.

According to Minister of Forestry and Plantation Decree No. 146 of 1999 (KM146), the definition of revegetation is a business or replanting activity on a former mine site. Revegetation is carried out through the following stages of activity: the stages of the preparation of the plant's technical design, field supply, seedlings / nursery procurement, implementation of planting and maintenance of plants.

Revegetation is replanting activities on former mining land in an effort to avoid land erosion, build habitat for wildlife, biodiversity, improve productivity and soil stability and improve environmental conditions. Ecologically, plant species can adapt to the local climate but not soil conditions. For this reason, it is necessary to choose suitable species, with local conditions, especially for fast-growing species, which can change the microclimate on the former mining land. To support the success in restoring former mining land, steps such as improvement of pre-planting land, selection of suitable species, and use of fertilizer are carried out. To evaluate the success rate of plant growth on former mining land can be from the percentage of growth power, the percentage of canopy closure, growth of root growth, addition of species on the land, increased humus, reduced erosion and function as a natural filter. In this way it can be seen how far the level of success achieved in restoring former mining land (Rahmawaty, 2002.)

Revegetation is a post-mining area planting activity with selected plants. Revegetation begins with planting cover crops and trees, and maintaining plants (Adman, 2012). The success of revegetation on former mining land is highly determined by many things including aspects of landscape structuring, fertility of planting and planting media and crop maintenance. Landscape management is closely related to aspects of soil and water conservation and land use planning for mines.

Eucalyptus is a small trunked tree plant. Its branches hang down. The name eucalyptus refers to its white, multi-layered bark with a peeling surface, taper leaf shape, with leaf bones parallel to the spear, the flowers are white. According to Brophy and Doran (1996) mentioned that eucalyptus spread naturally in the Maluku islands, East Island, northern and southwestern Australia. This species grows at an altitude of 5 to $400 \mathrm{~m}$ above sea level, with an average rainfall of 1,300 to $1,750 \mathrm{~mm}$ per year. The forestry research and development agency in the introduction to eucalyptus cultivation states that in general eucalyptus is relatively easy to plant, coinciding with grumosol, latosol and regosol soils.

Eucalyptus is able to grow both on marginal lands and in areas of swamps and water puddles, able to adapt to soils with poor drainage, fire resistance and tolerance to soils with low to high salinity. Eucalyptus in a variety of site conditions, both in the highlands and lowlands bordering coastal forests and growing monoculture. In addition, eucalyptus is resistant to heat and fire. Eucalyptus can live and grow again in 1 year with the condition of the leaves that can be picked. Eucalyptus roots consist of taproots, lateral roots, and secondary roots. The roots are straight and grow downward, lateral roots grow in the neck of the roots at 
the beginning of growth. Secondary roots spread at a depth of about $20 \mathrm{~cm}$ below the surface of the soil (Sunarto, 2003 in Kusumajati, E., 2017).

The white wooden trunk is round and straight with a slight branching. With good growth conditions, eucalyptus can grow into trees with a height reaching $35 \mathrm{~m}$ and a diameter reaching $100 \mathrm{~cm}$ (Sunarto, 2003 in Kusumajati, E., 2017). However, eucalyptus can grow into shrubs if the growth conditions are lacking, besides the growth of eucalyptus can be manipulated to get the shape of shrubs by picking the dau since the plant is still young. Eucalyptus bark white or brownish white consisting of thin sheets that are easily peeled off, the flaking, does not interfere with the growth of eucalyptus (Sunarto, 2003 in Kusumajati, E., 2017).

In the book introduction to eucalyptus plants explained that eucalyptus leaves are green with thick appearance, not shiny and hairy. According to Sunarto (2003) eucalyptus leaves are always green even in the dry season. The leaves are straight or curved with a length of between 5 to $10 \mathrm{~cm}$ and a width of between 1 to $4 \mathrm{~cm}$ and with 7 leaf bones with a length of between 3 to $11 \mathrm{~cm}$ on each leaf blade. The young shoots are covered by thick, soft feathers and spread out in lengths between 0.3 to $2 \mathrm{~mm}$.

In the book introduction of eucalyptus plants also mentioned that eucalyptus plants are types of plants that have quite an important role, among them in the eucalyptus essential oil industry produce eucalyptus oil obtained by refining. The main ingredient contained in eucalyptus oil is a sineol content that contains drugs. It is a potential plant for land rehabilitation activities from both ecological and economic aspects. Ecologically the development of eucalyptus plants in degraded land, among others, is to support land conservation efforts and the use of marginal land into productive land. Economically the development of eucalyptus plants can be used as a business / industry both for household scale up to large scale. Wood from eucalyptus plants can be used as building material. Eucalyptus includes strong grade wood with a durable class, in the area of South Kalimantan and South Sumatra the type of eucalyptus subspecies cumingiana is known as galam and its wood is widely used as building material (Sunarto, 2003).

The selection of eucalyptus species for post-mining revegetation activities refers to three (3) variables, namely the analysis of land suitability of eucalyptus plants on former coal mining land, financial feasibility analysis of eucalyptus cultivation and analysis of community perceptions of the planting of eucalyptus on former coal mining land.

\section{LAND SUITABILITY}

The issue of land suitability is something that needs attention in an effort to use more optimally. Land use is a direction of land use based on land capability. Pandeli and Muhammad (2009) say that land suitability is the suitability of a land for certain uses. So that the reclamation activity can run well, it must know the suitability of the land to the allotment to be carried out, such as allotment for plantations, forestry, agriculture and so on. At premining it is necessary to consider and make plans that show the land arrangements at the time of post-mining. In addition, the compost (Mangkoedihardjo and April, 2012) amendmend may be necessary to optimize reclamation.

Sofyan (2007) said that land characteristics are the characteristics of recognition or attributes of a plot of land. Land characteristics for land evaluation purposes, namely: topographic maps, soil maps, and climate and rainfall data.

Land evaluation is done by comparing or matching land characteristics with land use requirements / plant requirements. For example the suitability of plants to the height of the place, where tea and quinine plants are more suitable in cold regions (highlands), while rubber, palm and coconut are more suitable in lowland areas. 
Important aspects of spatial planning, regional spatial planning is an effort to formulate efforts to use space optimally and efficiently as well as sustainably for human business activities in order to realize the level of community prosperity to be achieved within a certain period of time. According to Pandeli and Muhammad (2009) that in order to guarantee land use based on its suitability, in the increasingly large use of space, it is necessary to pay attention to and consider land use planning or space, so that land can be utilized and utilized effectively by paying attention to the values of basic human conceptions, communities and existing ecosystems.

Suitability of land to plant species, selection of plant species (trees) is the main key in determining the success rate of revegetation. The selection of vegetation to achieve new ecosystem conditions with low erosion rates, optimal productivity and a sustainable environment needs to be done selectively with the right type of plant, so that ecosystem components as producers (flora), consumers (fauna), and decomposers can be formed immediately (Subowo, 2011).

Several approaches for selecting plant types (Setyo, 2008) are:

1. Adaptability is the selected species is a tree that can adapt to the local environment, can be done by evaluating potential local tree species, choosing non-local species that have grown in the local area.

2. Growth speed. The first priority is the type of plant that is fast growing and strong and deep roots.

3. Maintenance techniques. Keep in mind the cultivation techniques such as nursery techniques, transfer time to the field, and disease pests.

4. Plant availability. Selected plants should be easily searched and available in sufficient quantities.

5. In order for plants to grow well, the soil conditions must be ideal according to the needs of the plant so that land suitability needs to be made according to the type of plant. Evaluation can be done by distinguishing between classes of land that are classified as suitable $(\mathrm{S}=$ Saitable) and land that is not suitable $(\mathrm{N}=$ Not - Saitable).

\section{CONCLUSION}

To find out how land suitability uses eucalyptus plants (Melaleuca leucadendra) and Sengon (Paraserianthes falcataria) on former coal mining land, land suitability analysis is needed, the results can be used to support the main research objective, namely the study of reclamation of former coal mining land using eucalyptus plants and Sengon.

\section{REFERENCES}

[1] Adisoemarto, Soenarto. 1994. Fundamentals of Soil Science. Erlangga, 2008, Jakarta.

[2] Adman B., 2012. The Potential of Fast-Growing Local Tree Types for Environmental Recovery in Post-Coal Land (Case Study at PT. Singlurus Pratama, East Kalimantan). Diponegoro University Postgraduate Thesis. Semarang.

[3] Al-Rosyid, LM and Mangkoedihardjo, S. (2019). Relationship between BOD/COD Ratio and Octanol/Water Partition Coefficient for Glucose, Lactose, Sucrose, Formaldehyde, Acetic Acid and Oxalic Acid. International Journal of Civil Engineering and Technology, 10(01), pp. 691-696.

[4] Barrow, C. J., 1991. Land Degradation: Development and Breakdown of Terrestrial Environment. Published by the Press Syndicate of the University for Cambridge. USA.

[5] Brophy, J. J., dan Doran, J. C., 1996. Essential Oils of Tropical Asteromyrtus, Callistermon and Melaleuca Species. ACIAR Monografi No. 40 Canberra. 
[6] Djati Murjanto. 2011. Soil Characterization and Development in the Former Coal Mine Reclamation Land. Kaltim Prima Coal. Bogor Agricultural Institute Graduate School.

[7] KM146, (1999) Decree of the Minister of Forestry and Plantation number 146 of 1999 in the form of Guidelines for Reclamation of Former Mining in Forest Areas, Ministry of Forestry and Plantation, Jakarta.

[8] Kusumajati, E., 2017. Teaching Material for Introduction of Eucalyptus Plants, In Training on Capacity Building for Communities in the Utilization of Eucalyptus NTFPs.

[9] Law 4, (2009) Law Number 4 of 2009 concerning Minerals and Coal, Ministry of Energy and Mineral Resources, Jakarta.

[10] Madhu Nakirekanti, Dr.Raja Murali Prasad, Eliyaz Mahammad, K.Narsimha Reddy and D. Khalandar Basha, Coal Mining Safety Monitoring System, International Journal of Mechanical Engineering and Technology. 8(12), 2017, pp. 542-550

[11] Law 23, (2014) Law Number 23 Year 2014 concerning Regional Government, Ministry of Home Affairs, Jakarta.

[12] Lubis, M., 1997. The Development of Indonesia's Coal Supply Industry Trade and Investment Issue, Paper Presented at APEC Coal Trade and Investment Liberalization and Facilitation Workshop, August 5, Jakarta.

[13] Mangkoedihardjo, S. and April, SAL. (2012). Compost on Evapotranspiration Bed Planted With Yellow Flag for Treatment of Wastewater Containing Anionic Surfactant. Journal of Applied Sciences Research, 8(3): 1630-1633.

[14] Pandeli and Muhammad (2009), Basic Principles of Conserving the Landscape of Gadjah Mada University, Pess, Yogyakarta.

[15] PM18, (2008) Regulation of the Minister of Energy and Mineral Resources number 18 of 2008 concerning Mine Reclamation and Closure, Ministry of Energy and Mineral Resources, Jakarta.

[16] Qomariah, R., 2003. Impact of Coal Mining Permit (PETI) on Land Quality and Social Economic Resources of the Community in Banjar District, South Kalimantan Province, Thesis, Postgraduate, Bogor Agricultural Institute, JMHT Vol. XVI, (2): 63-72, August 2010 ISSN Scientific Article: 2087-046972.

[17] Rahmawaty, 2002. Restoration of Former Mining Land Based on Ecological Rules, Faculty of Agriculture, University of North Sumatra, Medan.

[18] Setyo (2008). Land Reclamation of Open Mining Scales with Environmental Insights.

[19] Singh, N, J. 2004. Morphological, Thermal And Rheological Properties of Starches From Different Botanical Sources Food Chemistry $81: 219-231$.

[20] Sitorus, M., 2003. The Effect of Giving Natural Phosphate Stones and Arbuscular Vesicular Mycorrhiza on the Availability and Concentration of P Corn Leaves on Ultisols. Thesis. University of Jambi Faculty of Agriculture. Jambi.

[21] Sofyan R, (2007) Evaluation of Land Suitability with Sample Directions for Laan Use in West Aceh District, Center for Land Research and World Agroforestry Center, Bogor.

[22] Subowo, 2011. Open Environment Friendly Mining System and Post-Mining Reclamation Efforts to Improve Land and Land Biodiversity Quality, Journal of Land Resources, Vol. 5 No. 2, December 2011, Bogor.

[23] Sunarto, H., 2003. Cultivation and Eucalyptus Refining. Canisius Publisher, Yogyakarta

[24] Andrey Alexandrovich Sidorenko, Vladimir Viktorovich Ivanov, Sergey Alexandrovich Sidorenko, Numerical Simulation of Rock Massif Stress State at Normal Fault at Underground Longwall Coal Mining, International Journal of Civil Engineering and Technology (IJCIET), 10(1), 2018, pp. 844-851 